\title{
AIDS and prevalence of antibody to human immunodeficiency virus (HIV) in high risk groups in Thailand
}

\author{
AMNUAY TRAISUPA,* CHAINARONG WONGBA,* AND DAVID N TAYLOR $\dagger$ \\ From the *VD Control Division, Bangrak Hospital, and the †Department of.Bacteriology, Armed Forces \\ Research Institute of Medical Sciences, (United States Army Medical Component), Rajvithi Road, \\ Bangkok, Thailand
}

SUMMARY Since September 1984, six cases of acquired immune deficiency syndrome (AIDS) and 11 cases of AIDS related complex (ARC) have been reported in Thailand. All people with AIDS were homosexual or bisexual men; two were Thai and the rest were European or American. Nine of the 11 people with ARC were homosexual or bisexual men, one was the female sexual partner of a man with AIDS, and one was a Thai man who had lived in the United States of America for several years, but denied having had any homosexual contact. Nine of the 11 people with ARC were Thai. In a survey in April 1985 at a resort area near Bangkok, antibodies to human immunodeficiency virus (HIV) (confirmed by western blot) were detected in $2.4 \%$ of 127 homosexual men and none of 77 female prostitutes. In a more extensive survey in October 1985 , antibodies were detected in $0.8 \%$ of 720 homosexual men, but none of 2880 female prostitutes or 309 sexually active heterosexual men. HIV has been introduced into Thailand primarily by homosexual transmission. The public health policy of Thailand concerning AIDS is discussed.

\section{Introduction}

The acquired immune deficiency syndrome (AIDS) was first reported in the developing world in $\mathrm{Haiti}^{1}$ and now seems to be epidemic in central Africa, ${ }^{2}$ but so far there is little evidence that AIDS has been introduced into Asia. In 1985 there were 2.4 million visitors to Thailand, about a third of whom came from north America, Europe, and Australia, countries where AIDS is becoming increasingly prevalent. Because the importation of AIDS into Thailand is of real concern, we reviewed the prevalence of AIDS in Thailand, assessed the prevalence of antibodies to human immunodeficiency virus (HIV) in high risk groups, and describe the measures taken by the Thai government to prevent and control AIDS in Thailand.

REPORTED CASES OF AIDS AND AIDS RELATED COMPLEX (ARC) IN THAILAND

AIDS was first reported in Thailand in September 1984 (Anuwat Limsuwan, personal communication), three years after the first cases of AIDS were reported

Address for reprints: Dr D Taylor, Department of Bacteriology, AFRIMS, Rajvithi Road, Bangkok 10400, Thailand

Accepted for publication 4 September 1986. in the United States. ${ }^{3}$ Since 1984 six cases of AIDS have been reported, all in homosexual or bisexual men. Two were Americans, two were Europeans, and two were Thais.

The first case of AIDS in a Thai citizen was both acquired and first diagnosed in the United States. This patient returned to Thailand during the late stages of his illness for supportive care and died two months after his return. The second case of AIDS in a Thai was diagnosed in 1985 in a bisexual man aged 27 who had never travelled outside Thailand. ${ }^{4}$ He presented with a febrile illness and was found to have disseminated cryptococcosis. He had a low T4:T 8 ratio and was seropositive for antibodies to HIV. He had had sexual contact for four to five years with a European homosexual man and for two years with a Thai woman. His male contact had no symptoms, a normal $T$ cell ratio, and no antibodies to HIV. His female contact was in good health, but had generalised lymphadenopathy, an abnormal $\mathrm{T}$ cell ratio, and antibodies to HIV. She denied having had sexual relations with other people.

Eleven patients with AIDS related complex (ARC) have been reported in Thailand. All had antibodies to HIV as shown by the enzyme linked immunosorbent 
assay (ELISA), and nine of 11 ELISA results were confirmed by the western blot assay (which was performed in two cases). Only two of 11 people with ARC were foreigners, the rest were Thais. Among Thais, one patient with ARC was the female sexual partner of the second man with AIDS and another was a Thai man who had been living in the United States of America for several years but denied having had homosexual contact. The remaining nine patients (including two foreigners) were homosexual or bisexual men. All people with ARC had generalised lymphadenopathy, and three had constitutional symptoms (fatigue, malaise, or fever). Six had low $\mathrm{T}$ cell ratios ranging from $0.78-0.94$ (normal $\geq 1 \cdot 0$ ). All except the first two patients gave a history of sexual contact with American or European men.

\section{SURVEY OF ANTIBODIES TO HIV \\ Methods}

In April 1985 we collected serum samples from 127 asymptomatic Thai homosexual men and 77 female prostitutes living and working at a beach resort near Bangkok. The samples were sent frozen on dry ice to the Walter Reed Army Institute of Research, Washington DC, USA.

From October 1985 to January 1986 we collected serum from a total of 3909 people including 476 homosexual male prostitutes, 916 female prostitutes, and 95 heterosexual men in Bangkok, and from 244 homosexual male prostitutes, 1964 female prostitutes, and 214 heterosexual men in the beach resort near Bangkok.

Serum samples from both surveys were screened for antibodies to HIV using an ELISA (Abbott Laboratories, North Chicago, USA) ${ }^{5}$ and positive results were confirmed by the western blot assay. ${ }^{6}$
Results

In the April survey at the beach resort three (2\%) of 127 homosexual men and none of 77 female prostitutes had antibodies to HIV by ELISA confirmed by western blot. The results of the second survey are show in the table.

One of three people with antibodies to HIV in the April survey was available for follow up. He was a man aged 28 who was asymptomatic and had generalised, non-tender, lymphadenopathy. Ten months previously he had been to Europe where he had had sexual contact with three homosexual men. Since then he had had only one Thai male sexual partner, who was HIV antibody negative. In the second survey the mean age of the six homosexual men who were ELISA and western blot positive was $281 / 2$ (range 22-37) years; one was a foreigner and five were Thai.

Discussion

In a previous survey in February to June 1985, serum samples from 600 people in Bangkok had been examined for antibodiy to HIV. ${ }^{7}$ One of 101 homosexual male prostitutes was ELISA and western blot positive; two of 100 patients with thalassaemia were weakly ELISA positive and western blot negative; and 100 female prostitutes, 100 heterosexual males attending a sexually transmitted disease clinic, and 99 parenteral drug abusers were all seronegative for HIV. Antibodies to HIV were found in a man aged 20 who gave a history of multiple sexual exposure to Thai and foreign men and women in the previous year.

In Thailand all patients with AIDS and nine of 11 persons with ARC were homosexual or bisexual men. The exceptions were a Thai heterosexual man who had lived in the United States of America and a Thai heterosexual woman who had had sexual contact with a man with AIDS. The surveys confirmed that

TABLE Prevalence of antibodies to human immunodeficiency virus (HIV) in high risk groups in Thailand, October 1985 to January 1986

\begin{tabular}{lccc}
\hline & & \multicolumn{2}{c}{ No (\%) with antibodies to HIV by: } \\
\cline { 3 - 4 } Sexual activity and location & No tested & ELISA & Western blot \\
\hline Homosexual male prostitutes in: & & & $0 *$ \\
Bangkok & 476 & $11(2 \cdot 3)$ & $6(2 \cdot 5)$ \\
Beach resort & 244 & $6(2 \cdot 5)$ & $6(0 \cdot 8)$ \\
Total & 720 & $17(2 \cdot 4)$ & 0 \\
Female prostitutes in: & 916 & $1(0 \cdot 1)$ & 0 \\
Bangkok & 1964 & $10(0 \cdot 5)$ & 0 \\
Beach resort & 2880 & $11(0 \cdot 4)$ & 0 \\
Total & & & 0 \\
Sexually active heterosexual men in: & 95 & 0 & 0 \\
Bangkok & 214 & 0 & 0 \\
Beach resort & 309 & & \\
Total & & 0 & \\
\hline
\end{tabular}

ELISA = enzyme linked immunosorbent assay.

*Eight out of 11 tested by western blot. 
exposure to HIV was confined to sexually active homosexual men at a level of 2-3\%. Sexual contact with American or European homosexual men seems to be an important risk factor for Thais. This is similar to the finding in Denmark, where seropositivity to HIV in homosexual men was strongly associated with sexual exposure to American homosexual men. ${ }^{8}$

\section{MEASURES ADOPTED TO CONTROL AND PREVENT AIDS IN THAILAND}

In August 1985 a national advisory committee on AIDS control was established. It is chaired by the Director General of the Communicable Disease Control Department and is composed of 18 members from government and private medical institutions. The responsibilities of the committee are to provide guidelines for the diagnosis and treatment of AIDS, to provide recommendations for the prevention and control of AIDS, to educate health care workers and the public about AIDS, and to encourage research on AIDS. Through this committee guidelines for hospital staff on the care and management of people with AIDS and the handling of contaminated materials associated with AIDS have been widely distributed in Thailand, and public health information has been provided to the news media to educate the public.

To increase surveillance of AIDS a government sponsored STD clinic was established in Bangkok to screen homosexual men for AIDS, and serological tests to detect antibodies to HIV were established at government hospitals. The Venereal Disease Division and the Division of Epidemiology of the Ministry of Health were given responsibility for investigating patients and tracing contacts, and on 1 May 1985 AIDS became a disease notifiable to the Ministry of
Health of Thailand. Under the provisions of this law any clinic or hospital must report to the health authorities patients suspected of having AIDS. Moreover, the Ministry of Public Health has proposed that AIDS should be made a quarantinable disease. By such a law any foreigner with AIDS could be ordered to leave the country.

We thank Kanchana Panikabutra, Samreung Sangsue, Somsak Bovornseripatai, Stan Weiss, and Donald Burke for their support with one of the surveys.

\section{References}

1. Pape JW, Liautaud B, Thomas F, Mathurin J-R, St Amand MMA, Boncy $M$. Characteristics of the acquired immunodeficiency syndrome (AIDS) in Haiti. N Engl J Med 1983; 309:945-50.

2. Biggar RJ. The AIDS problem in Africa. Lancet 1986; i:7982.

3. Centers for Disease Control. Pneumocystis pneumonia - Los Angeles. MMWR 1981;30:250-2.

4. Phanuphak P, Locharernkul C, Panmuong W, Wilde H. A report of three cases of AIDS in Thailand. Asian Pac J Allergy Immunol 1985;3:195-9.

5. Weiss SH, Goedert JJ, Sarngadharan MG, Bodner AJ. Screening test for HTLV III (AIDS agent) antibodies: specificity, sensitivity, and applications. JAMA 1985;253:221-5

6. Safai B, Sarngadharan MG, Groopman JE, Arnett K, Popovic M, Sliski A. Seroepidemiological studies of human $\mathrm{T}$-lymphotropic retrovirus type III in acquired immunodeficiency syndrome. Lancet 1984 ; i:1438-40.

7. Wangroongsarb $Y$, Weniger BG, Wasi C, Traisupa A, Kunasol P, Rojanapithayakorn W. Prevalence of HTLV-III/LAV antibody in selected populations in Thailand. Southeast $A$ sian $J$ Trop Med Public Health 1985;16:517-20.

8. Melbye M, Biggar RJ, Ebbesen P, Sarngadharan MG, Weiss SH, Gallo RC. Seroepidemiology of HTLV-III antibody in Danish homosexual men: prevalence, transmission, anḍ,disease outcome. Br Med J 1984;289:537-75. 